\title{
Toegang tot het recht in de rechtsstaat
}

\author{
Nathalie Franziska Hendrika Schnabl
}

\section{Inleiding}

Is toegang tot het recht een kenmerk van de rechtsstaat? In maatschappelijke, politieke en juridische discussies over de rechtsstaat lijkt dit bijna een vanzelfsprekendheid. Zo is toegang tot het recht een terugkerend thema in de hoorzittingen over de 'staat van de rechtsstaat' in de Eerste Kamer, ${ }^{1}$ stelde EHRM-rechter Linos-Alexandre Sicilianos dat de toegang tot de rechter een onderdeel is van de rechtsstaat ${ }^{2}$ en vraagt ook Folkert Jensma in zijn columns voor de $N R C$ regelmatig aandacht voor problemen rondom de toegang tot het recht. ${ }^{3}$ Ook de toeslagenaffaire kan in dit rijtje worden genoemd. ${ }^{4}$

In dit artikel worden diverse rechtsstaattheorieën uit de academische literatuur besproken en wordt onderzocht in hoeverre deze theorieën toegang tot het recht erkennen als onderdeel van de rechtsstaat. Daarbij dient allereerst te worden opgemerkt dat - ondanks de verschillen - de rechtsstaat en de rule of law op één lijn worden gesteld. ${ }^{5}$ In dit artikel zal worden aangesloten bij het onderscheid, dat is gemaakt door Barber, tussen de legalistische en niet-legalistische rechtstaattheorieën. De legalistische benadering legt de focus op de juridische procedure en op de structuur en formulering van wetten. Daartegenover plaatst Barber de niet-legalistische benadering van de rechtsstaat die sociale en politieke rechten tot uitgangspunt neemt. Deze rechten zijn niet direct gerelateerd aan de structuur van de wet of aan juridische procedures. ${ }^{6}$ Het onderscheid tussen de legalistische en niet-legalistische benaderingen stelt ons in staat te onderzoeken in hoeverre het belang van toegang tot het recht en eventuele drempels in deze toegang worden meegewogen in de verschillende rechtsstaattheorieën.

1 Eerste Kamer der Staten-Generaal, 'Kamer debatteert over staat van de rechtsstaat', 22 mei 2018, geraadpleegd op 27 augustus 2020. https://www.eerstekamer.nl/nieuws/20180522/kamer_ debatteert_over_staat_van_de.

2 Linos-Alexandre Sicilianos, 'The Rule of Law and the European Court of Human Rights: the independence of the judiciary,' Council of Europe, 28 februari 2020, geraadpleegd op 27 augustus 2020. https://www.echr.coe.int/Documents/Speech_20200228_Sicilianos_Montenegro_ENG.pdf.

3 Zie bijvoorbeeld Folkert Jensma, 'Eigenlijk wankelt het hele eerlijke proces,' NRC, 9 mei 2020. https://www.nrc.nl/nieuws/2020/05/09/eigenlijk-wankelt-het-hele-eerlijke-proces-a3999175.

4 Nederlandse Orde van Advocaten, 'Oproep NOvA: investeer in stelsel van gefinancierde rechtsbijstand', 19 januari 2021. https://www.advocatenorde.nl/nieuws/oproep-nova-investeer-in-stelselvan-gefinancierde-rechtsbijstand.

5 De eisen aan de rechtsstaat en de rule of law worden gelijkgesteld, zowel op grond van Europese regelgeving en jurisprudentie, zie artikel 2 VEU, als in de academische literatuur, zie bijvoorbeeld Eddy Bauw et al., Togadragers in de rechtsstaat. De juridische professies en de toegang tot het recht (Den Haag: Boom Juridisch, 2019), 19.

6 Nicholas W. Barber, 'Must Legalistic Conceptions of the Rule of Law Have a Social Dimension?', Ratio Juris 17, no. 4 (2004), 475 en 81, https://doi.org/10.1111/j.1467-9337.2004.00278.x. 
Doordat een eenduidige definitie van toegang tot het recht ontbreekt, is niet altijd duidelijk wat 'toegang tot het recht' in een bepaalde context betekent. In dit artikel sluit ik mij aan bij het uitgangspunt dat Jeremy Waldron hanteert met betrekking tot actieve participatie en human dignity, ${ }^{7}$ een definitie die in grote mate overeenstemt met de definitie van Joseph Raz als hij spreekt over de letterlijke betekenis van de rule of law. ${ }^{8}$ Om te kunnen participeren in een samenleving moeten individuen in staat zijn om hun handelen af te stemmen op het recht. Daarnaast moeten individuen in het geval van conflicten een officiële instantie kunnen vragen te beslissen over de toepassing van rechtsnormen. 'Officiële instanties' dient in dit verband niet beperkt uitgelegd te worden. Zo kunnen individuen terecht bij de rechterlijke macht, maar ook Alternative Dispute Resolution of Online Dispute Resolution behoren tot de mogelijkheden. Kortom: individuen moeten in staat zijn om te participeren in een rechtsorde. Om te participeren is enige kennis van het recht vereist. Kennis van het materiële recht alleen voldoet echter niet; individuen moeten ook hun rechten kunnen effectueren.

Toegang tot het recht is - zoals Nicholas Barber en Waldron opmerken - niet eenvoudig te bereiken voor individuen, ${ }^{10}$ terwijl zelfredzaamheid - ook in Nederland - in veel gevallen verondersteld wordt. Het recht is steeds belangrijker geworden nu de (Nederlandse) samenleving sterk is gejuridiseerd: $:^{11}$ met pestprotocollen op scholen, geformaliseerde klachtprocedures in de zorg, en in het familieleven door middel van subsidies voor gastouders. Individuele relaties worden steeds meer in juridische termen gevat. ${ }^{12}$ De globalisering heeft het rechtssysteem ook een internationale dimensie gegeven. ${ }^{13}$ Tekenend is dat zelfs in het SBS-programma Wordt $u$ al geholpen? met enige regelmaat wordt verwezen naar organisaties die individuen kunnen helpen met het effectueren van consumentenrecht onder het EU-recht. Deze ontwikkelingen en voorbeelden illustreren dat toegang tot het recht breder dient te worden opgevat dan toegang tot de rechter. Het ziet namelijk op de mogelijkheid voor individuen om gebruik te maken van het recht om hun leven in te richten en op de mogelijkheid, bij conflicten of schendingen van deze rechten, deze rechten te effectueren.

In paragraaf twee van dit artikel wordt de legalistische benadering van de rechtsstaat besproken. Uit deze bespreking zal blijken dat het belang van toegang tot het recht in de legalistische benadering veelal wordt genegeerd, veronachtzaamd of slechts opgemerkt en niet verder geanalyseerd. Zo wordt in de legalistische bena-

7 Jeremy Waldron, 'The Concept and the Rule of Law', Sibley Lecture Series 29 (2008): 9; Jeremy Waldron, 'How law protects dignity', Cambridge Law Journal 71, no. 1 (2012), 208.

8 Joseph Raz, The Authority of Law: Essays on Law and Morality (Oxford: Oxford University Press, 2011), 213-14.

$9 \quad$ Waldron, 'How law protects dignity', 202 en 208.

10 Barber, 'Must Legalistic Conceptions of the Rule of Law Have a Social Dimension?', 484-486; Waldron, 'How law protects dignity', 215.

11 Lars C. Blichner en Anders Molander, 'Mapping Juridification', European Law Journal 14, no. 1 (2008), 42.

12 Blichner en Molander, 'Mapping Juridification,' 47.

13 Koen de Feyter, 'Law Meets Sociology in Human Rights', Development and Society 40, no. 1 (2011), 49-50. 
dering toegang tot het recht in brede zin vaak onterecht gelijkgesteld met toegang tot de rechter waarbij als oplossing rechtsbijstand wordt aangedragen. In de derde paragraaf wordt de niet-legalistische benadering van de rechtsstaat besproken. Uit deze bespreking zal blijken dat in deze benadering het toegangsvraagstuk wel centraal staat. De sociale dimensie van de rechtsstaat is een nadere uitwerking van de niet-legalistische rechtsstaatbenadering. Kortgezegd ziet de sociale dimensie van de rechtsstaat op het feit dat een juridisch systeem een bepaalde mate van welzijn - sociaaleconomische en politieke rechten - nodig heeft als voorwaarde voor de effectiviteit van het recht. ${ }^{14}$ Sociaaleconomische omstandigheden van individuen in de samenleving beïnvloeden de werking van de rechtsstaat. In dit artikel sluit ik mij aan bij Barbers stelling dat de sociale dimensie van de rechtsstaat erkend dient te worden, maar stel ik ook dat de theorievorming over de sociale dimensie van de rechtsstaat nog pril is en verder moet worden uitgedacht.

De belangrijkste leemte in de theorie van Barber ziet op de toepasbaarheid van de sociale dimensie. Kort gezegd ontbreekt er een analytisch kader om de problemen in de toegang tot het recht voor individuen op een systematische wijze te bespreken. Dit vormt niet alleen een beperking op de theorievorming van de sociale dimensie van de rechtsstaat, maar ook op de maatschappelijke, politieke en juridische discussies over de rechtsstaat. Dit uit zich in allerlei, veelal willekeurige, oplossingen voor problemen met betrekking tot toegang tot het recht. Een analytisch kader zorgt, zoals gezegd, voor een systematische bespreking van de drempels in de toegang tot het recht en de mogelijke oplossingen.

Op basis van de kapitalen van Pierre Bourdieu doe ik in de vierde paragraaf een voorstel om het begrip van de sociale dimensie van de rechtsstaat nader te preciseren. Kort gezegd: individuen hebben geld, kennis en vaardigheden en een sociaal netwerk (economisch, cultureel en sociaal kapitaal) nodig voor toegang tot het recht, maar niet ieder individu beschikt (in gelijke mate) over deze kapitalen. Het is dan ook een illusie te veronderstellen dat iedereen gelijke toegang heeft tot het recht. ${ }^{15}$ Het doel van dit verbeterde concept van de sociale dimensie van de rechtsstaat is om problemen rondom toegang tot het recht te identificeren, om zo te beoordelen in hoeverre juridische regelingen voldoende aandacht hebben voor toegang tot het recht. Het doen van eventuele specifieke aanbevelingen valt buiten het bereik van dit artikel.

\section{Legalistische rechtsstaattheorieën en toegang tot het recht}

In de academische literatuur zijn er veel theorieën over wat de rechtsstaat inhoudt en welke kenmerken deze heeft - of moet hebben. Slechts enkele auteurs daarvan zijn Albert Venn Dicey, Lord Tom Bingham, Joseph Raz, Lon Luvois Fuller, Jeremy Waldron, Gianluigi Palombella, Jeff King, Nicholas Barber en Martin Krygier. In de volgende twee paragrafen bespreek ik in hoeverre er aandacht is voor de drempels 
in toegang tot het recht aan de hand van verschillende rechtstaattheorieën. Deze verschillende theorieën worden, zoals in de inleiding aangegeven, ingedeeld aan de hand van de legalistische en niet-legalistische rechtsstaatbenaderingen. In deze paragraaf staat de legalistische rechtsstaatbenadering centraal, waarbij de formele, de materiële en de procedurele rechtsstaattheorieën zullen worden besproken. Deze verschillende rechtsstaattheorieën leiden doorgaans tot het opstellen van zogenoemde laundry lists, ${ }^{16}$ 'waslijsten' van elementen waaraan de rechtsstaat moet voldoen. In de woorden van Waldron: 'legal philosophers discuss the various requirements of the rule of law and they compete with one another to come up with more and more carefully formulated lists of requirements' ${ }^{17} \mathrm{Ik}$ zal beargumenteren dat de formele, materiële en procedurele rechtsstaattheorieën verschillende benaderingen zijn met andere criteria. Echter, door het onderscheid dat Barber maakt tussen legalistische en niet-legalistische rechtsstaattheorieën blijkt dat deze benaderingen in grote mate overeenstemmen: zij zien alle drie op de legalistische zijde van de rule of law. Met andere woorden, deze benaderingen leggen de nadruk op de structuur en formulering van wetten en de juridische procedures.

Het eerste onderscheid dat binnen de legalistische rechtsstaatbenadering kan worden gemaakt is tussen de formele en materiële rechtsstaattheorieën: bestaat de rechtsstaat enkel uit formele criteria of doet de inhoud van het recht er ook toe? Dit verschil heeft grote consequenties voor de minimumeisen waaraan de rechtsstaat moet voldoen. De formele rechtsstaattheorieën richten zich enkel op de vorm van het recht. Enkele bekende criteria zijn dat de wet algemeen moet zijn, afdoende bekend moet zijn gemaakt, niet met terugwerkende kracht mag gelden, intern consistent moet zijn en tevens bestendig moet zijn. ${ }^{18}$ De materiële rechtsstaattheorieën stellen ook eisen aan de inhoud van het recht. ${ }^{19}$ Zo kan respect voor individuele grondrechten als materieel vereiste van de rechtsstaat worden gezien. Als in het rechtssysteem geen aandacht is voor deze rechten kan van een rechtsstaat geen sprake zijn. De staat heeft volgens de materiële rechtsstaattheorie een zorgplicht ten aanzien van de samenleving. ${ }^{20}$

Naast de formele en materiële rechtsstaattheorieën, heeft Waldron de procedurele rechtsstaattheorie geplaatst: deze theorie vormt een aanvulling op de formele rechtsstaattheorie. De rechtsstaat benadrukt niet alleen de voorspelbaarheid van vaststaande regels, maar ook de procedurele aspecten van de juridische praktijk zijn essentieel. ${ }^{21}$ Waldron benadrukt hierbij het belang van de rechterlijke macht, die door middel van procedures op een eerlijke en effectieve wijze de rechten en

16 Jeremy Waldron, 'Is the Rule of Law an Essentially Contested Concept (In Florida)?', Law and Philosophy 21 (2002), 5.

17 Jeremy Waldron, 'Preface', Hague Journal on the Rule of Law 11, no. 2-3 (2019), 251.

18 Lon L. Fuller, The Morality of Law: Revised Edition (New Haven: Yale University Press, 1969), 39.

19 Paul P. Craig, 'Formal and substantive conceptions of the rule of law: an analytical framework,' Public Law (1997), 467; Zie voor een lijst met de bekendste formele criteria Fuller, The Morality of Law: Revised Edition, 39; John Finnis, Natural Law and Natural Rights (New York: Oxford University Press, 1980), 270-271; Raz, The Authority of Law: Essays on Law and Morality, 217-218.

20 Bauw et al., Togadragers in de rechtsstaat. De juridische professies en de toegang tot het recht, 22-25.

21 Waldron, 'The Concept and the Rule of Law,' 5. 
plichten van individuen vaststelt nadat de partijen de mogelijkheid hebben gehad om gehoord te worden en bewijs en argumenten aan te dragen. ${ }^{22}$ Individuen hebben daarbij het recht zich te laten vertegenwoordigen door een raadsman. ${ }^{23}$

In de literatuur botsen de rechtsstaattheorieën regelmatig met elkaar. Materiële rechtsstaatdenkers oordelen dat de rechtsstaat in slechts een formele of procedurele vorm een leeg concept is. Met alleen de formele criteria zouden er nog steeds grote schendingen kunnen plaatsvinden, zoals het onderdrukken van burgers of zelfs genocide. ${ }^{24}$ De formele rechtsstaatdenkers verwijten de materiële rechtsstaatdenkers dat de rechtsstaat in hun theorie als middel wordt ingezet om andere idealen te realiseren, zoals mensenrechten, menselijke waardigheid of politieke participatie. ${ }^{25}$ Het introduceren van een materiële dimensie zou, zo menen de formele rechtsstaatdenkers, leiden tot een competitie van idealen en individuele aanspraken. ${ }^{26}$ Waldron noemt deze scheiding tussen de rechtsstaat enerzijds en de mensenrechten en democratie anderzijds ook wel een seperation thesis, ${ }^{27}$ die ook tot uitdrukking komt in de werken van Hans Kelsen ${ }^{28}$ en Raz. ${ }^{29}$ Individuele rechten hebben volgens deze denkers geen plaats in het academische debat over de rechtsstaat. Daarnaast heeft een materiële rechtsstaattheorie het gevaar dat de rechtsstaat in een zwakke positie komt doordat de rechtsstaat kan worden bekritiseerd indien de bijeffecten uitblijven, terwijl de rechtsstaat op zichzelf wel functioneert. ${ }^{30}$

Hoewel de procedurele en formele rechtsstaattheorieën elkaar in het algemeen goed aanvullen, kunnen ook zij echter op gespannen voet met elkaar komen te staan. De formele rechtstaattheorie hecht grote waarde aan de negatieve vrijheid, oftewel het voorkomen van inmenging in de vrijheid van individuen. De procedurele rechtsstaattheorie, daarentegen, onderschrijft het belang van actieve participatie van individuen in het recht. ${ }^{31}$ Hierbij moet de kanttekening worden geplaatst dat Waldron niet de intentie heeft dat toegang tot het recht voor iedereen is weggelegd. Het gaat er voornamelijk om dat het recht toegankelijk is 'to anyone who is

22 Waldron, 'The Concept and the Rule of Law', 20.

23 Waldron, 'How law protects dignity', 216.

24 Tom Bingham, The Rule Of Law (London: Penguin Books, 2011), 67.

25 Grant Lamond, 'The Rule of Law', in The Routledge Companion to Philosophy of Law, A. Marmor (red.) (New York and London: Routledge, 2012), 501.

26 Jeremy Waldron, 'The Rule of Law', in The Stanford Encyclopedia of Philosphy, ed. E.N. Zalta (Fall 2016 Edition: Metaphysics Research Lab, Stanford University, 2016). https://plato.stanford.edu/ archives/fall2016/entries/rule-of-law/.

27 Jeremy Waldron, The Rule of Law and the Measure of Property (Cambridge: Cambridge University Press, 2012), 13.

28 Kelsen meende het juridische domein te moeten bewaken tegen woorden als rechtvaardigheid om zo 'die Rechtswissenschaft von allen ihr fremden Elementen [zu, toevoeging door auteur] befreien'. Hans Kelsen, Reine Rechtslehre. Einleitung in die Rechtswissenschaftliche Problematik (Leipzig und Wien: Franz Deuticke, 1934), 1.

29 Ook Raz is voorstander van een scheiding tussen de rechtsstaat en waarden als democratie, rechtvaardigheid, gelijkheid of menselijke waardigheid. Het zou dan gaan om de vraag wat de rechtsstaat zou moeten zijn, in plaats van wat de rechtsstaat is. Raz, The Authority of Law: Essays on Law and Morality, 210-212.

30 Martin Krygier, 'The Rule of Law: Pasts, Presents, and Two Possible Futures', Annual Review of Law and Social Science 12 (2016), 216-218.

31 Waldron, 'The Concept and the Rule of Law', 8. 
sufficiently interested, and available in particular to those who make a profession of being public norm-detectors (lawyers, as we call them) and who make that expertise available to anyone who is willing to pay for it". ${ }^{32}$ Een selecte groep in de samenleving krijgt daarmee daadwerkelijk direct toegang tot het recht. De juristen, zo lijkt de suggestie te zijn, geven deze toegang door aan een bredere groep individuen. Daaruit vloeit de suggestie voort dat toegang tot het recht afdoende is gerealiseerd door toegang tot rechtsbijstand te verlenen. Naast het gegeven dat toegang tot het recht dreigt te worden gereduceerd tot toegang tot de rechter, roept dit weer nieuwe vragen op. Wordt het probleem met betrekking tot toegang tot het recht niet slechts verplaatst?

Al met al zijn er dus verschillen tussen de formele, procedurele en materiële rechtsstaattheorieën. Toch komen deze theorieën in een belangrijke mate overeen. Alle benadrukken de juridische kant van de rechtstaat: de wettelijke en juridische procedure, de structuur en formulering van wetten. ${ }^{33}$ Zowel de wetgever als de rechter maken het mogelijk dat individuen hun leven kunnen plannen. ${ }^{34}$ Echter, alles buiten het juridische systeem wordt niet meegenomen in de rechtstaatanalyse. Sociale en economische omstandigheden die ertoe (kunnen) leiden dat individuen hun leven niet kunnen plannen omdat zij geen toegang hebben tot het recht - zowel de materiële normen als de formele procedures - blijven buiten beschouwing. ${ }^{35}$

Het voorgaande betekent echter niet dat de drempels tot de toegang tot het recht voor individuen geheel worden genegeerd; het blijft bij het opmerken dat er mogelijk drempels bestaan. Zo benoemt Raz de gevaren van lange wachttijden en hoge kosten, ${ }^{36}$ en Waldron erkent het gevaar van private arbitraire macht. ${ }^{37}$ Ook verwijst Waldron naar omstandigheden waarin individuen geen goede publieke sprekers zijn, ongeletterd zijn, onbekend zijn met het recht of de taal niet kunnen spreken. ${ }^{38}$ In een enkel geval wordt tegenover deze drempels een oplossing geplaatst, meestal het mogelijk maken van juridische vertegenwoordiging in een procedure. ${ }^{39}$ Deze oplossing wordt echter niet gekoppeld aan onderliggende sociaaleconomische omstandigheden die de specifieke drempels tot gevolg hebben. Alle sociaaleconomische omstandigheden leiden tot een simpele catch-all oplossing: rechtsbijstand. Er worden geen pogingen gedaan te verduidelijken welke diverse problemen in de toegang tot het recht in een specifieke samenleving voor individuen rijzen en welke oplossingen daartegenover dienen te staan. Individuen worden daarmee aan de ene kant geacht zelfredzaam te zijn, maar aan de andere kant blijven diepere reflecties op de drempels in de toegang tot het recht uit. ceptions of the Rule of Law Have a Social Dimension?', 483; Bingham, The Rule Of Law, 97. 
Het blijft daardoor onduidelijk welke voorwaarden noodzakelijk zijn om de juridische criteria te vervullen. In andere woorden, de academische literatuur moet naast de juridische dimensie van de rechtsstaat ook expliciet aandacht besteden aan de sociale dimensie, aan de sociaaleconomische omstandigheden van groepen en individuen in een samenleving. De oplossingen die nodig zijn voor de problemen met betrekking tot toegang tot het recht zijn niet enkel juridisch van aard. Oplossingen kunnen ook uit andere disciplines komen en zijn dus mogelijk economisch, juridisch, sociologisch of politicologisch van aard. In de volgende paragraaf zullen de niet-legalistische rechtsstaattheorieën worden besproken als reactie op deze leemte in het academisch debat.

\section{Niet-legalistische rechtstaattheorieën en toegang tot het recht}

In de vorige paragraaf zijn de legalistische rechtsstaattheorieën besproken. In deze paragraaf wordt vervolgd met de niet-legalistische theorieën. Een exclusieve focus op de legalistische zijde van de rechtsstaat - de procedures, structuur en de formulering van het recht - resulteert volgens Barber in een onvolledig beeld van de werking van de rechtsstaat in de samenleving. Om te begrijpen hoe de rechtsstaat in de samenleving functioneert, is ook van belang om andere academische disciplines te betrekken in de discussie over de rechtsstaat. Rechtsstaatdiscussies kunnen profiteren van deze niet-legalistische inzichten. ${ }^{40}$

Het is belangrijk om op te merken dat de niet-legalistische rechtstaattheorieën in feite een holistische benadering van de rechtsstaat voorstaan. Dit betekent dat naast de juridische dimensie oog dient te zijn voor de sociaaleconomische omstandigheden in een samenleving. Sociale factoren beïnvloeden de werking van de rechtsstaat. De niet-legalistische rechtsstaattheorieën erkennen expliciet dat sociale factoren invloed hebben op het functioneren van het rechtssystemen en voegen om deze reden individuele rechten toe aan de rechtsstaatdefinitie, individuele rechten die niet direct gerelateerd zijn aan de structuur van het recht of het juridisch proces. ${ }^{41}$ De rechtsstaat en de rule of law zijn universele idealen, ${ }^{42}$ maar hun werking is, zoals Martin Krygier stelt, 'dependent on the complex social, economic, and political contexts into which it intervenes'. ${ }^{43}$ Enkel juridische vereisten vaststellen is onvoldoende om de realisering van de telos van de rechtsstaat te waarborgen.

40 Barber, 'Must Legalistic Conceptions of the Rule of Law Have a Social Dimension?', 475; Nicholas W. Barber, 'The Rechtsstaat and the Rule of Law', The University of Toronto Law Journal 53, No. 4 (2014), 445-447.

41 Barber, 'Must Legalistic Conceptions of the Rule of Law Have a Social Dimension?', 481 en 484.

42 Ook landen die vanuit een Westers perspectief vaak bekritiseerd worden hebben veelal de rechtsstaat of rule of law erkend, zoals Rusland en China. Zie ook Tamanaha, On the Rule of Law: History, Politics, Theory, 92-93.

43 Martin Krygier, 'Four Puzzles about the Rule of Law', in Getting to the Rule of Law, J.E. Flaming (red.) (New York and London: New York University Press, 2011), 86-87. 
Barber noemt The International Congress of Jurists $1959^{44}$ en Trevor Allan ${ }^{45}$ als voorbeelden van niet-legalistische rechtsstaattheorieën. Deze rechtsstaattheorieen neemt Barber als uitgangspunt voor de sociale dimensie. De sociale dimensie van de rechtsstaat is daarmee een aanvulling op de juridische dimensie van de rechtstaat en geen vervanging. ${ }^{46}$ Naast een juridische dimensie kent de rechtsstaat dus een sociale dimensie. De inkleuring van de sociale dimensie is afhankelijk van de sociale, economische en politieke context waarin de rechtsstaat functioneert. In een grote samenleving die sterk gejuridiseerd is en een complex rechtssysteem kent, zal de sociale dimensie wellicht andere invulling krijgen dan het geval is in een tribale samenleving. ${ }^{47}$

Erkenning van de sociale dimensie is noodzakelijk om te beoordelen of individuen daadwerkelijk toegang hebben tot het recht; dat betekent, zoals eerder uiteengezet, dat zij kunnen participeren in de rechtsorde. Dit is dus breder dan toegang tot de rechter. Het hebben van een rechtsstaat heeft weinig toegevoegde waarde als er geen toegang is tot het recht doordat individuen geconfronteerd worden met onoverkomelijke drempels. Door ook de sociale dimensie van de rechtsstaat in ogenschouw te nemen, blijkt dat in de praktijk kanttekeningen kunnen worden geplaatst bij de juridische zelfredzaamheid van individuen. Zo blijkt dat een hoge mate van (juridische) zelfredzaamheid wordt verwacht van individuen. ${ }^{48}$ Misschien is deze verwachting zelfs wel onrealistisch hoog. De samenleving bestaat uit verschillende individuen en mogelijk hebben slechts enkelen van hen toegang, terwijl anderen juist worden buitengesloten. Bepaalde groepen hebben een kwetsbare positie als gesproken wordt over toegang tot het recht, zoals individuen met een lage opleiding of uit een lagere inkomensgroep. ${ }^{49}$ Deze kwetsbare positie zou er niet toe mogen leiden dat zij (feitelijk) geen toegang tot het recht hebben. Toegang tot het recht is geen bijeffect van de rechtsstaat, maar moet worden gezien als een essentiële voorwaarde voor de effectiviteit daarvan. Een rechtsstaat kan alleen functioneren als individuen hun handelen kunnen afstemmen op het recht, dat zij een beroep op de rechter kunnen doen om hun rechten te effectueren, en dat zij advies kunnen inwinnen van juristen. Ontbreken deze voorwaarden dan is het mogelijk dat individuen worden overgelaten aan 'the mercy of the powerful. ${ }^{50}$ Het is van belang om op te merken dat deze powerful niet beperkt zijn tot de overheid. Zowel

44 International Congress of Jurists, The Rule of Law in a Free Society (New Delhi, India, 1959).

45 Trevor Robert Seaward Allan, Constitutional Justice. A Liberal Theory of the Rule of Law (Oxford: Oxford University Press, 2001), 2.

46 Barber, 'Must Legalistic Conceptions of the Rule of Law Have a Social Dimension?', 485.

47 William Lucy, 'Access to Justice and the Rule of Law', Oxford Journal of Legal Studies 40, no. 2 (2020), 401.

48 Hilke Grootelaar et al., Toegang tot het recht: een actueel portret (Utrecht: University Utrecht, 2014), 8; Ella Schepel en Bernard de Leest, 'Een holistische kijk op zelfredzaamheid', in Toegang tot recht. Beschouwingen aangeboden aan Mies Westerveld, Diana de Wolff (red.) (Den Haag: Boom Juridisch, 2019), 170.

49 Marijke J. ter Voert en Carolien M. Klein Haarhuis, Geschilbeslechtingsdelta 2014. Over verloop en afloop van (potentieel) juridische problemen van burgers, Wetenschappelijk Onderzoek- en Documentatiecentrum (Meppel: Boom Lemma Uitgevers, 2015), 68-69.

50 Barber, 'Must Legalistic Conceptions of the Rule of Law Have a Social Dimension?', 484. 
publieke als private actoren kunnen powerful zijn, ${ }^{51}$ zoals blijkt uit de toenemende macht van online platforms. ${ }^{52}$

Toegang tot de rechter en kenbaarheid van het recht valt moeizaam te realiseren als individuen te arm zijn om naar de rechter te gaan of geen of zeer beperkte scholing hebben gehad. ${ }^{53}$ Dat de gang naar de rechter en andere instellingen op papier goed geregeld is, betekent dus niet dat er daadwerkelijk gebruik kan worden gemaakt van het recht. Het gaat erom dat individuen daadwerkelijk toegang hebben tot het recht, dat zij kunnen handelen in overeenstemming met het recht en dat zij zich tot officiële instanties kunnen wenden om hun geschillen te laten beslechten. Alleen dan werkt de rechtsstaat zowel op papier als in de praktijk. Barber introduceert de sociale dimensie van de rechtsstaat door te stellen dat 'a legal system requires some level of material well-being if the purported laws are to prove effective'. ${ }^{54}$

Anders dan de legalistische rechtsstaattheorieën, zijn de niet-legalistische rechtsstaattheorieën nog niet doorontwikkeld. Barber en King ${ }^{55}$ noemen de sociale dimensie van de rechtsstaat bij naam. Wat echter ontbreekt, is een nadere analyse van deze sociale dimensie van de rechtsstaat. Om deze reden kent hun theorie dezelfde leemte als de materiële rechtsstaattheorieën. Welke sociaaleconomische omstandigheden moeten worden meegenomen in de beoordeling van de werking van de rechtsstaat? Welke drempels zijn er in de toegang tot het recht? Welke oplossingen kunnen mogelijk worden voorgesteld? Barber noemt enkele - vrijwel willekeurige - drempels en oplossingen rondom toegang tot het recht, zoals de hogere gerechtelijke kosten, recht op onderwijs, en gratis juridische bijstand. ${ }^{56}$ De vraag is hoe kan worden beoordeeld of, en waarom, deze voorbeelden passen binnen de sociale dimensie van de rechtsstaat. Wat ontbreekt, is een systematische analyse van de sociale dimensie, een theoretisch kader met behulp waarvan bepaald kan worden wanneer toegang tot het recht in het geding is en welke rechten en verplichtingen de overheid mogelijk heeft om de toegang tot het recht te waarborgen. Met andere woorden, er worden op dit moment allerhande oplossingen geboden zonder eerst systematisch in kaart te brengen welke problemen er binnen een specifieke samenleving spelen. Een duidelijk kader ontbreekt om te beoordelen welke individuele rechten noodzakelijk zijn. De 'vergaarbak' aan problemen en oplossingen komt niet alleen voor in de bespreking van de sociale dimensie van de rechts-

51 Jeff King, "I-CONnect Symposium on "Constitutional Boundaries" - The Social Dimension of the Rule of Law', Int'l J. Const. Blog, 27 april 2018, geraadpleegd op 1 juli 2020. www.iconnectblog. com/2018/04/i-connect-symposium-on-constitutional-boundaries-the-social-dimension-of-therule-of-law.

52 Reijer Passchier, Artificiële intelligentie en de rechtsstaat (Den Haag: Boom juridisch, 2021), 82-88.

53 Barber, 'Must Legalistic Conceptions of the Rule of Law Have a Social Dimension?', 483-484.

54 Barber, 'Must Legalistic Conceptions of the Rule of Law Have a Social Dimension?', 483.

55 Op dit moment werkt King aan een uitgebreide bijdrage over de sociale dimensie. Jeff King, 'The Social Dimension of the Rule of Law (draft)', in The Cambridge Handbook of Constitutional Theory, R. Bellamy en J. King (red.) (Cambridge University Press, 2021 (forthcoming)). Deze bijdrage is gepresenteerd op 14 februari 2020 in Rotterdam. Daarnaast werkt King aan een monografie over de sociale dimensie.

56 Barber, 'Must Legalistic Conceptions of the Rule of Law Have a Social Dimension?', 484. 
staat in de academische literatuur. Ook in maatschappelijke, politieke en juridische discussies over de rechtsstaat is systematiek niet altijd aanwezig. Individuen kunnen verschillende drempels ervaren in de toegang tot het recht en deze drempels vereisen soms andere oplossingen. ${ }^{57}$

Individuen hebben bepaalde middelen (kapitalen) nodig voordat zij kunnen profiteren van de rechtsstaat. Dit geldt niet alleen voor de toegang tot kennis over het recht, maar ook voor de verwerkelijking daarvan, het realiseren van oplossingen en van de toegang tot de rechter. In alle gevallen dient de rechtzoekende te beschikken over geld, kennis en een netwerk om een ingang in het rechtssysteem te vinden. Bourdieu heeft dit aangeduid als economisch kapitaal, cultureel kapitaal en sociaal kapitaal. ${ }^{58}$ Mogelijk blijven bepaalde drempels onderbelicht in de debatten over toegang tot het recht doordat een bepaald kapitaal veel meer aandacht geniet dan andere. Daarbij is het belangrijk om vooraf op te merken dat een combinatie van economisch, sociaal en cultureel kapitaal de positie van individuen in het rechtssysteem beïnvloedt. De toegang tot het recht als individu is niet afhankelijk van een kapitaal maar van een complex samenspel van de verschillende kapitalen. Bij beleidskeuzes, zoals bezuinigingen op de rechtspraak, moeten al deze factoren in ogenschouw worden genomen om een afweging te kunnen maken. In de rest van dit artikel formuleer ik een analytisch kader aan de hand van deze drie kapitalen van Bourdieu. Door dit kader voor de sociale dimensie van de rechtsstaat kunnen de specifieke drempels in de toegang tot het recht worden geïdentificeerd en kunnen aanbevelingen worden gedaan om de toegang tot het recht te verbeteren.

\section{De elementen van de sociale dimensie van de rechtsstaat}

De kapitalen, economisch, cultureel en sociaal, geformuleerd door Bourdieu, zijn onderdeel van zijn reproductietheorie, ${ }^{59}$ die hij heeft toegepast op het onderwijssysteem van Frankrijk in de jaren zeventig van de vorige eeuw. ${ }^{60}$ Zijn kapitalen zijn, zoals zal blijken uit deze paragraaf, echter ook bruikbaar om een kader te schetsen om de toegang tot het recht te beoordelen. Hiermee wordt een kader gecreëerd om de sociale dimensie van de rechtsstaat vorm te geven. Welke sociaaleconomische omstandigheden dienen te worden meegewogen in de beoordeling van de werking van de juridische dimensie van de rechtsstaat? Hoe wordt in juridische, politieke en maatschappelijke debatten omgegaan met deze verschillende kapitalen? In dit ar-

57 Zo worden economische drempels en drempels met betrekking tot de kennis van het recht van burgers niet altijd van elkaar gescheiden. Zie bijvoorbeeld Ruth. de Bock, 'Civiele procedures: differentiatie,' in Naar vernieuwing van de (civiele) rechtspleging, Theodoor Groenewald et al. (red.) (Den Haag: Boom Juridisch, 2019), 116-17; Kamerstukken II 2018/19, 31753, no. 155; De Balie, 'In de rij voor de rechter. Een debat over de rechtspraak onder druk', 7 september 2020. https:// debalie.nl/programma/in-de-rij-voor-de-rechter-07-09-2020/.

58 Pierre Bourdieu, 'The Forms of Capital,' in Handbook of Theory and Research for the Sociology of Education, John G. Richardson (red.) (Westport: Greenwood, 1986).

59 Dit is de theorie die stelt dat de klassenstructuur zichzelf steeds opnieuw reproduceert doordat individuen zich zelden kunnen bewegen naar een andere sociale klas.

60 Bourdieu, 'The Forms of Capital', 46-58. 
tikel zullen slechts de kapitalen aan bod komen en niet Bourdieu's gehele reproductietheorie.

Het eerste kapitaal dat wordt besproken is economisch kapitaal. Met economisch kapitaal wordt bedoeld dat individuen financiële middelen nodig hebben voor toegang tot het recht. Deze financiële middelen kunnen bestaan uit geld, maar ook uit bezittingen. ${ }^{61}$ Toegang tot het recht brengt kosten met zich mee, voornamelijk voor het voeren van rechterlijke procedures. ${ }^{62}$ Echter, niet alle individuen hebben de beschikking over voldoende economisch kapitaal om deze kosten te dekken.

Over het algemeen wordt erkend dat economisch kapitaal een drempel kan vormen in de toegang tot het recht. Zo heeft het Europees Hof voor de Rechten van de Mens (EHRM0 zich meermalen uitgelaten over de hoogte van de griffierechten. Deze kosten zijn toegestaan om de rechtspraak te ontlasten, maar er dient te allen tijde een balans te zijn tussen het publieke en individuele belang. ${ }^{63}$ Zelfs van minvermogenden wordt veelal een eigen bijdrage verwacht. Wel is er een korting op de eigen bijdrage voor mensen die eerst langs het Juridisch Loket gaan. ${ }^{64}$ Daarnaast is er aandacht voor de kosten van juridische bijstand. ${ }^{65}$ Ten slotte kost toegang tot het recht ook veel tijd. ${ }^{66}$ Het verkrijgen van (juridische) informatie, het opstellen van documenten en het voeren van rechtszaken is tijdsintensief. De omvang en hoogte van deze kosten is veelal niet voorzienbaar voor individuen omdat deze factoren afhankelijk zijn van de tijd die de zaak kost en de complexiteit daarvan. Dit brengt onzekerheid met zich mee voor individuen. Juist om deze reden is de redelijke termijn een belangrijk element van het recht op een eerlijk proces. ${ }^{67}$

Het gebrek aan economisch kapitaal is een sterk bediscussieerd onderwerp in het debat over de toegang tot het recht. Een aantal mogelijke drempels blijven echter bestaan. Zo bestaat er niet in alle gevallen recht op gefinancierde rechtsbijstand. Alleen in het geval van een criminal charge en indien de belangen van een behoorlijke rechtspleging daartoe vereisen zijn staten verplicht om gefinancierde rechtsbijstand te verlenen aan individuen. In het geval van civil rights and obligations heeft het EHRM bepaalt dat het recht op gefinancierde rechtsbijstand onder andere afhankelijk is van de belangen van de klager, de complexiteit van het recht of de procedures, de mogelijkheid van de klager om zichzelf te verdedigen en de vraag of juridische bijstand een wettelijke verplichting is. ${ }^{68}$ Dit leidt ertoe dat er in kantonzaken geen recht op gefinancierde rechtsbijstand is, terwijl uit onderzoek blijkt dat

61 Bourdieu, 'The Forms of Capital', 47.

62 Expliciet opgenomen als rechtsstaatcriteria door Waldron en Raz Waldron, "The Concept and the Rule of Law', 20 en 23; Raz, The Authority of Law: Essays on Law and Morality, 217.

63 Chorbadzhiyski and Krasteva v. Bulgaria, app. no. 54991/10 para. 59 (ECtHR 2 April 2020).

64 Artikel 2 lid 6 van het Besluit eigen bijdrage rechtsbijstand.

65 Artikel 6 lid 3 sub c EVRM; artikel 47 Handvest; artikel 14 IVBPR; artikel 18 Grondwet.

66 Martin Gramatikov et al., A Handbook for Measuring the Costs and Quality of Access to Justice (Apeldoorn, Antwerpen and Portland: Maklu, 2010), 30-31.

67 Joachim Meese, 'Art. 6 - Verdrag tot bescherming van de rechten van de mens en de fundamentele vrijheden', in Janneke Gerards et al. (red.), Sdu Commentaar Europees Verdrag voor de Rechten van de Mens, (Den Haag: Sdu, 2019), aant. C.7 (online, bijgewerkt 31 maart 2019). Airey v. Ireland, app. no. 6289/73 para. 26 (ECtHR 9 October 1979). 
ook in kantonzaken veelal met rechtshulp wordt geprocedeerd ${ }^{69}$ Een ander voorbeeld is het bestuursrecht. In de recente toeslagenaffaire ontvingen de ouders geen gefinancierde rechtsbijstand, omdat de toevoegingsaanvraag standaard werd afgewezen met tekstcode 130. Deze code betekent dat individuen worden geacht zelfredzaamheid genoeg te zijn in bestuursrechtelijke geschillen. ${ }^{70}$ Ook bezuinigingen of hervormingen op de gefinancierde rechtshulp worden met argusogen bekeken. Deze bezuinigingen en hervormingen zouden kunnen leiden tot uitsluiting van toegang tot het recht. ${ }^{71}$

Naast economisch kapitaal is cultureel kapitaal van belang. Cultureel kapitaal ziet op de kennis en vaardigheden van individuen. ${ }^{72}$ In het specifieke geval van toegang tot het recht gaat het om kennis en vaardigheden die individuen nodig hebben om hun weg te vinden in het recht. Zo moeten zij zich bij juridische problemen staande kunnen houden en moeten zij zichzelf kunnen verdedigen in een procedure door middel van het aanvoeren van juridische en feitelijke argumenten en het ondervragen van getuigen. Daarnaast is basiskennis van het recht noodzakelijk om gedrag te laten reguleren door het recht. Individuen moeten in staat zijn het recht dat geldt in de samenleving te gebruiken om hun leven in te richten. Onvoldoende kennis van of verkeerde opvattingen over het recht kan bijvoorbeeld leiden tot onbegrip of rechtsconflicten. Individuen nemen bijvoorbeeld genoegen met een voucher bij annulering van een reis of voorstelling terwijl zij liever hun geld zouden terugkrijgen. Ook de beoordeling of het recht niet met terugwerkende kracht wordt toegepast of de uitvoerende macht niet buiten zijn bevoegdheden treedt, vereist een bepaalde mate van basiskennis van het recht. ${ }^{73}$

Uiteraard hebben individuen in juridische procedures veelal de mogelijkheid zich te laten vertegenwoordigen door een advocaat of gemachtigde, maar, zoals eerder aangegeven, niet altijd. Zonder het recht op gefinancierde rechtsbijstand dienen individuen alle kosten zelf te betalen of hun eigen belangen zelf te behartigen, zonder de vereiste kennis. Dit is problematisch te noemen nu zelfs advocaten zich genoodzaakt zien zich te specialiseren in een bepaald rechtsgebied omdat het ondoenlijk is om alle kennis te vergaren. ${ }^{74}$ Daarnaast wordt enige mate van zelfredzaamheid verondersteld. In de praktijk is deze nadruk op zelfredzaamheid

69 Rogier Hartendorp, 'Digitale platforms: een vergroting van de toegang tot het recht', in Naar vernieuwing van de (civiele) rechtspleging, Theodoor Groenewald et al. (red.) (Den Haag: Boom Juridisch, 2019), 49-50.

70 'Gedupeerden toeslagenaffaire werd jarenlang rechtsbijstand ontzegd,' Nos Nieuws 2021, https:// nos.nl/artikel/2368153-gedupeerden-toeslagenaffaire-werd-jarenlang-rechtsbijstand-ontzegd. html; Raad voor Rechtsbijstand Kenniswijzer, 'W013 Geschil woon- of huurtoeslag', 1 december 2020. https://kenniswijzer.rvr.org/werkinstructies-toevoegen/woonrecht/w013-geschilwoon--of-huurtoeslag.html.

71 Grootelaar et al., Toegang tot het recht: een actueel portret, 16.

72 Tony Bennett, 'Introduction to the Routledge Classic Edition', in Pierre Bourdieu, Distinction. A Social Critique of the Judgement of Taste, trans. Richard Nice (London and New York: Routledge Classics, 2010), xviii.

73 Criteria geïntroduceerd door Raz, The Authority of Law: Essays on Law and Morality, 214-218.

74 Theodoor Groenewald, 'De rol van de advocaat in de civiele rechtspleging', in Naar vernieuwing van de (civiele) rechtspleging, Theodoor Groenewald et al. (red.) (Den Haag: Boom Juridisch, 2019), 62. 
echter niet altijd realistisch. Het recht en de juridische procedures, onderverdeeld in verschillende rechtsgebieden en procedures, zijn veelal technisch van aard en dus voor leken lastig te begrijpen. Door verregaande digitalisering en globalisering wordt dit verergerd. ${ }^{75}$ Het recht beïnvloedt alle aspecten van het leven en het recht is zonder meer complex door verschillende nationale en internationale regels, verschillende procedures per rechtsgebied en een legio aan jurisprudentie. Het privaatrecht verschilt hierin niet van het strafrecht. Daarnaast heeft het privaatrecht, evenals het strafrecht, een grote impact op het leven van individuen.

Als het gaat om aandacht voor cultureel kapitaal zijn er veel positieve punten te benoemen, zoals het gebruik van gebruiksvriendelijke procedures (de spreekuurrechter, de videorechter en de buurtrechter), het verminderen van archaïsch taalgebruik en het schrijven van teksten op B1 taalniveau. ${ }^{76}$ Daarnaast hebben staten een verzwaarde verantwoordelijkheid als het gaat om kwetsbare individuen, zoals minderjarigen, immigranten die de taal niet machtig zijn en gehandicapten. ${ }^{77}$ Toch zijn er ook verbeterpunten te noemen. Zo moet er, volgens Geerke van der Bruggen, naast stijl aandacht worden besteed aan de structuur en de inhoud van rechterlijke uitspraken. ${ }^{78}$ Recentelijk zijn er daarnaast initiatieven ontwikkeld op het niveau van de zogenoemde 'nuldelijn', oftewel op het niveau van de zelfhulp. Individuen kunnen via internet op een laagdrempelige en goedkope manier op weg geholpen worden binnen het rechtssysteem. Voorbeelden hiervan zijn de 'Rechtwijzer'79 en 'Uitelkaar'. ${ }^{80}$ Voor veel individuen zorgen internetinitiatieven voor een verbetering in de toegang tot het recht, maar niet voor iedereen. Voor bepaalde groepen lijkt de afstand juist toe te nemen omdat zij cultureel kapitaal missen; zij weten de weg op het internet naar de weg naar toegang tot het recht niet te vinden. De vraag is of een nieuwe groep kwetsbare individuen ontstaat, individuen die niet bekend zijn met, of niet de beschikking hebben over, digitale middelen.

Het derde en laatste kapitaal dat zal worden besproken is sociaal kapitaal. Sociaal kapitaal ziet volgens Bourdieu op de 'actual or potential resources which are linked to possession of a durable network or more or less institutionalized relationships of mutual acquaintance and recognition'. ${ }^{81}$ Individuen moeten de toegangsdeur van het rechtssysteem weten te vinden. In enkele gevallen weten individuen dit op eigen kracht te doen doordat zij over voldoende economisch en cultureel kapitaal beschikken en er geen verplichte procesvertegenwoordiging is, maar veelal kunnen

Anthony Giddens, The Consequences of Modernity (Cambridge: Polity Press, 1990), 64; Maurits Barendrecht, Krijn van Beek, en Sam Muller, Menselijk en rechtvaardig; is de rechtstaat er voor de burger?, HiiL (Den Haag, 2017), 3.

76 Deborah L. Rhode, Access to Justice (Oxford and New York: Oxford University Press, 2004), 86; Rapport visitatiecommissie gerechten, Goede rechtspraak, sterke rechtsstaat (Den Haag, 2019), 23.

77 Jill E.B. Coster van Voorhout, 'Commentaar op art. 6 EVRM: Verantwoordelijkheden van de procesdeelnemers', in Sdu Commentaar Europees Verdrag voor de Rechten van de Mens, (Den Haag: Sdu, 2019), C.13.2 (online, bijgewerkt 31 maart 2019).

78 Geerke van der Bruggen, 'Klare taal in uitspraken. Meer dan stijl alleen', NJB 2020/1808, 2024236.

79 Zie https://rechtwijzer.nl/.

80 Zie https://uitelkaar.nl/.

81 Bourdieu, 'The Forms of Capital', 51. 
mensen door de bomen het bos niet meer zien; zij hebben hulp nodig van anderen. Waar voorheen hulp veelal uit de traditionele netwerken van kerken, vakbonden en familie kwam, zijn de bronnen van sociaal kapitaal tegenwoordig het Juridisch Loket, de sociaal raadslieden en de rechtsbijstandverzekeringen, maar ook het aanzoeken van tolken en geschilbeslechters valt hieronder. ${ }^{82}$ Sociaal kapitaal is noodzakelijk voor individuen die onvoldoende cultureel of economisch kapitaal bezitten om zelfstandig te participeren in de rechtsorde.

Deze bronnen van sociaal kapitaal zijn echter veelal afhankelijk van subsidies. Door de jaren heen is veel bezuinigd op deze eerstelijnshulp. Hierdoor zijn de openingstijden verkort, medewerkers ontslagen en telefoonkosten gestegen. ${ }^{83}$ Dit kan een belemmering vormen voor de toegang tot het recht. Individuen kunnen niet meer op een laagdrempelige manier hulp vinden. Daarnaast hebben rechters en advocaten te maken met een hoge werkdruk, terwijl niet alle kosten worden gedekt. ${ }^{84}$ De toegang tot het recht kan daarmee in het gedrang komen; steeds minder jonge advocaten kiezen voor de sociale advocatuur en de uitstroom is hoog. Waar Nederland in 2015 nog 7.520 sociale advocaten kende, is dit in 2019 teruggelopen tot $6.883 .{ }^{85}$ De bereikbaarheid en beschikbaarheid van de sociale advocatuur, en daarmee sociaal kapitaal, nemen hierdoor mogelijk af.

De sociale dimensie in ogenschouw nemende, blijkt dat individuen bepaalde middelen (kapitalen) dienen te bezitten voordat zij toegang hebben tot het recht en dus kunnen profiteren van de rechtsstaat: kapitalen die niet elke individu in dezelfde mate bezit. In deze paragraaf zijn deze drie kapitalen uiteengezet. In de eerste plaats dienen individuen te beschikken over voldoende economische middelen om de toegang tot het recht te betalen. Ten tweede dienen individuen te beschikken over de kennis en vaardigheden om te kunnen participeren in de sterk gejuridiseerde, globaliseerde samenleving. Individuen dienen in staat te zijn om hun eigen handelen te toetsen aan wet- en regelgeving. Daarnaast zijn er gevallen waarin het wenselijk is om een officiële instantie te laten beslissen over de toepassing van normen, bijvoorbeeld om geschillen te beslechten. Ook in deze procedures dienen individuen te kunnen participeren. Uiteraard kunnen individuen zich in deze procedures laten bijstaan of vertegenwoordigen door een rechtsbijstandverlener. Deze rechtsbijstandverlener moet echter wel worden betaald (of gefinancierd) en worden aangezocht. Alleen al het vinden van rechtsbijstand vereist een combinatie van de verschillende kapitalen.

Om tegemoet te komen aan de diverse drempels in de toegang tot het recht dienen wij uit te gaan van een rechtsstaattheorie die ook sociaaleconomische omstandigheden meeneemt in de beoordeling van het functioneren van de rechtsstaat. Mocht

82 Ter Voert en Klein Haarhuis, Geschilbeslechtingsdelta 2014. Over verloop en afloop van (potentieel) juridische problemen van burgers, 188.

83 'Persbericht: Bezuinigingen rechtsbijstand treffen Juridisch Loket', Het Juridisch Loket, 1 maart 2014, geraadpleegd op 27 augustus 2020. https://www.juridischloket.nl/actueel/ persbericht-bezuinigingen-rechtsbijstand-treffen-juridisch-loket/.

84 Rhode, Access to Justice, 12-13 en 142.

85 Bauw et al., Togadragers in de rechtsstaat. De juridische professies en de toegang tot het recht, 8. 
blijken dat er drempels zijn in de toegang tot het recht dan heeft de staat mogelijk een plicht tot het introduceren van individuele rechten. Alleen dan kunnen de legalistische criteria van de rechtsstaat worden verwezenlijkt. In paragraaf vier is gebleken dat dit op sommige onderdelen reeds is gerealiseerd. ${ }^{86}$ Het verder introduceren van individuele rechten is uiteindelijk een politieke kwestie, afgestemd op de sociale context waarin de rechtsstaat functioneert.

\section{Conclusie}

In dit artikel is besproken dat toegang tot het recht, anders dan in de maatschappelijke, politieke en juridische debatten, nog niet altijd erkend wordt als element van de rechtsstaat. Toegang tot het recht wordt veelal genegeerd, veronachtzaamd of slechts opgemerkt en niet verder geanalyseerd. Toch kan niet ontkend worden dat sociaaleconomische omstandigheden invloed uitoefenen op de vervulling van de legalistische criteria. Zonder kennis van het recht kan het recht niet voorspelbaar zijn; zonder rechtsbijstand wordt de gang naar de rechter bemoeilijkt. Om te beoordelen welke individuele rechten noodzakelijk zijn, moet de politieke, sociale en economische context waarin de rechtsstaat functioneert in ogenschouw worden genomen. Alleen als de toegang tot het recht is gewaarborgd, kan het ideaal van de rechtsstaat worden bereikt. Voor het in ogenschouw nemen van de politieke, sociale en economische context waarin de rechtstaat functioneert, biedt het werk van Nicholas Barber een opening. De sociale dimensie van de rechtsstaat is in het academische debat echter nog onvoldoende uitgewerkt en er ontbreekt een theoretisch kader om te beoordelen uit welke elementen de sociale dimensie bestaat.

In dit artikel is op basis van de drie kapitalen die zijn geïntroduceerd door Pierre Bourdieu, economisch, sociaal en cultureel kapitaal, een analytisch kader geformuleerd. Om te kunnen beoordelen of de toegang tot het recht onder druk staat, moet worden geïdentificeerd hoe deze kapitalen worden meegewogen in maatschappelijke discussies, politieke besluiten en rechterlijke beslissingen. Door de drie kapitalen mee te nemen, kan het vraagstuk over de toegang tot het recht worden beoordeeld. Op deze manier kunnen problemen worden geïdentificeerd waarna geïnformeerd aanbevelingen kunnen worden gedaan, zowel voor het huidige beleid als voor de wenselijkheid van veranderend beleid. 